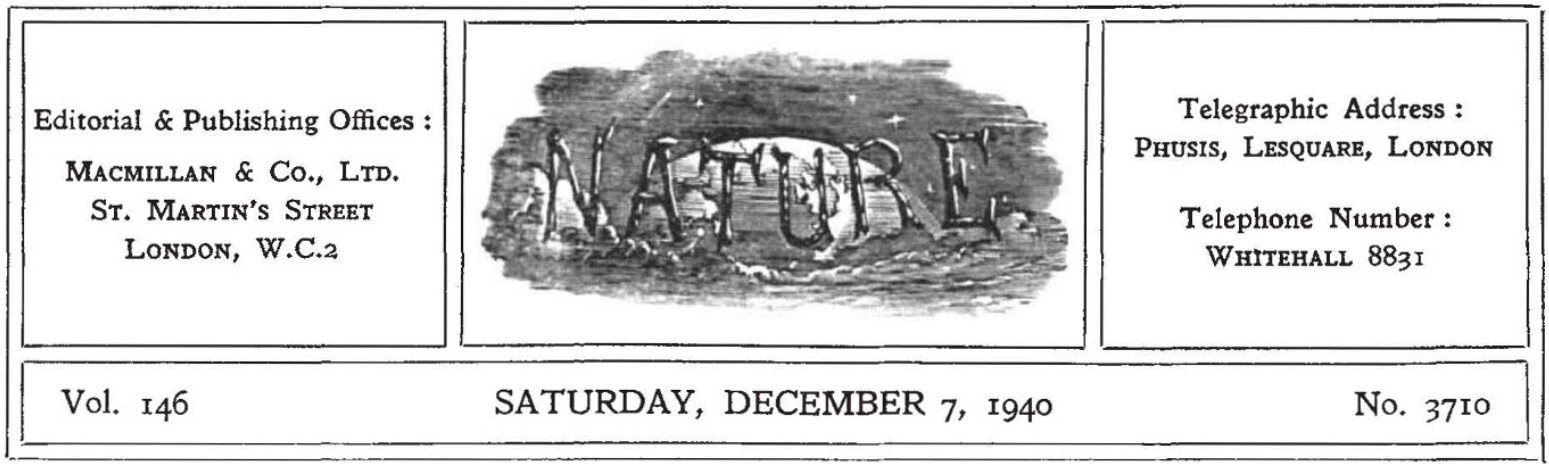

\title{
BRITISH AGRICULTURE IN WAR-TIME
}

IT T is all too true that as civilized life develops, its problems multiply and become more difficult to solve. In primitive agriculture man had but to contend with elemental forces that opposed him when he began to grow food, instead of merely hunting for it or gathering it. In modern agriculture we have not only to adjust our environment to the needs of particular crops and animals and to conserve soil fertility, but also to concentrate production in delimited areas to help maintain large industrial populations that live off the land, if not upon it. We have also to organize transport and distribution through a medley of middlemen and vested interests without causing the cauldron of social unrest to boil over. In wartime these problems are aggravated by disorganization of labour and transport, and by the vital need of producing as much food as possible in proximity to consuming centres.

Owing to the neglect of agriculture, to the huge growth of the industrial population, and to developments in submarine and aerial warfare, Great Britain is now at pains to maintain her food supplies ; and the difficulties of to-day are greater than those experienced in 1914, because since then we have lost some $2 \frac{1}{4}$ million acres of arable land and about one quarter of our agricultural workers, large areas of grassland have become derelict, death duties have deprived the land of capital and unpredictable prices have badly handicapped the progressive farmer. Our shipping, overseas investments, and exports have all declined. On the other hand, science applied to agriculture has shown how yields of many crops, including grass, can be increased, and how numerous plant and animal pests can be controlled; farm labourers are better paid, and the output efficiency per worker has increased ; the number of agricultural tractors has increased by 44 per cent since Septem. ber 1939 ; so far, there has been very little reduction in livestock numbers, and good stocks of essential foodstuffs have been stored, for man if not for beast.

The chief agricultural problem of the moment is the production of more home-grown human food, and closely related thereto are the problems of feeding-stuffs, prices, and labour. The weekly wage of the farm worker has been raised to a minimum of $48 s$., and although 70,000 workers left the land for other pursuits in the first ten months of war, this leak has now been sealed. Unremunerative prices have long been the bugbear of the farming community, and to-day price-fixing at profitable levels is vociferously demanded. Notwithstanding efforts of the legislature to make farming profitable by means of the Wheat Act of 1932, sugar-beet subsidies, and marketing boards run by producers, the outlook for farming has remained precarious, and ever mindful of his bad experience when the Corn Production Act was repealed in 1921, the farmer is naturally anxious for the future. There can be no argument that in peace-time efficient farming must be made remunerative; but too great and too frequent insistence on having good prices now, when many are sacrificing far more than their worldly wealth, is apt to alienate the sympathy of the urban electorate, upon whose votes the future prosperity of farming will depend. There is, however, no question that our farmers may be relied upon to pull their weight in the present emergency; and they will be encouraged by the recent assurance of the Minister of Agriculture that the present system of fixing prices in advance will be continued throughout the War and for one year afterwards. 
The provision of fodders and feeding-stuffs for livestock is especially important, because it affects the dietary of the whole nation. Thanks to a favourable climate, we produce sufficient grass and hay for nine months' supply', but the production is seasonal and the gap is filled largely by importing 'concentrates' (cereals, cereal offals and oilcakes) to the tune of about 9 million tons a year. These concentrates occupy much shipping space and involve currency payments abroad. Munitions of war and food for direct human consumption being of prior importance, we must now seek to compensate restricted imports of concentrates by growing more fodder at home, by eliminating wasteful feeding, and by reducing flocks and herds consonant with diminished imports. Now increased production of homegrown fodder competes with food production for direct human consumption, and it is well known that feeding man through animals involves great loss of nutrients ; for example, it takes $10 \mathrm{lb}$. of concentrates to provide $1 \mathrm{lb}$. of butter, and up to $20 \mathrm{lb}$. of wheat to produce $1 \mathrm{lb}$. of beef. Hence, in war-time, arable land growing human food is more important than grass or arable land growing food for stock.

One of the meritorious achievements of the Ministry of Agriculture has been the ploughing-up of more than two million acres of grassland in the first nine months of war, a good proportion of which has been used for growing oats and wheat. It is now planned to break up a further million acres of grassland, the selection of which will be much more difficult than the first two millions. No definite guidance has been given as to how newly broken land is to be cropped. The cropping must depend to some extent on the local conditions, but it seems reasonably certain that the bulk of it will be devoted to growing cereals, and increasing the acreage under potatoes, which so far have been somewhat neglected, leaving comparatively little for growing roots and other animal fodders. Some leeway may be made up by growing kale and catch crops of rape, rye, late-sown barley, etc., and, in general, higher yields can be obtaîned by a more liberal use of nitrogenous and phosphatic fertilizers. Various suggestions have been made for increasing supplies of home-produced feedingstuffs, such as utilization of all slaughter-house offals, predigestion of straw with alkali, and ensiling a million tons of grass for winter feed, but Dr. Norman Wright has already shown (NATURE, Aug. 24 , p. 251, and Nov. 30 , p. 712) that little substantial help can be expected from these sources, or even from the adoption of minimum standards of feeding ordinary rations.

The Minister of Agriculture has recently stated that during this winter allocations of feeding-stuffs not grown on the farm will probably be reduced to 70 per cent of normal supplies for dairy cattle, to about one half for other cattle and sheep, and to one third for pigs and poultry. This ruling is in line with the policy followed in Great Britain and in Germany during the War of 1914-18, and by Germany in Denmark and Holland at the moment ; it means a gradual slaughtering of livestock (except milch-cows), pigs and poultry being the first to suffer.

There is, however, something to be said for the view, shared by many, that pigs or poultry, or both, should have precedence over beef-cattle. The late Mr. Christopher Turnor, whose death is a great loss to British agriculture, recently stated that for more than ten years he had produced "excellent grass-fed beef and mutton on heavy clay pasture, properly treated, without using any imported cake or concentrates whatever". It would be encouraging to think that this practice could be, or would be, followed at all generally ; nevertheless, it suggests one means of helping to maintain our best beef-cattle and sheep. It therefore looks as if the Briton's dietary will gradually shift, at least during the war years, towards lactovegetarianism; and there is little doubt that the national health would not suffer thereby. A large proportion of our adult population, in particular sedentary folk and those who neither toil nor spin, could well give up half the meat they normally eat, and thrive on a dietary supply of some $60 \mathrm{gm}$. of protein a day (instead of the usually accepted 100-120 gm.), provided, of course, that other nutritional elements, especially vitamins and minerals, were consumed in adequate amounts.

The severe troubles of British agriculture, which began when cheap wheat from North America began to flood our markets in the late eighteen seventies, have never been boldly tackled by Government, and they have been aggravated by the intractable individualism of the farmer. Lack of vision on the part of our rulers has been the keynote of most of our lack of successes. In agriculture the need has always been for a comprehensive long-term policy, and one which would be compatible with war-time as well as peacetime conditions; instead of it, we have been 
treated with what Lord Bledisloe calls "hectic legislative patchwork". The outbreak of war in 1914 found us unprepared in almost every department of State, including agriculture. It was not until 1917 that the newly created Food Production Department began its successful labours ; but even this, as Sir Thomas Middleton has recently told us, was handicapped by the delay in adopting a policy. Delay and makeshift are the inevitable concomitants of lack of vision; and the story has been repeating itself to some extent during 193940. Although the present War began to brew in 1933 , practically the only serious preparatory step taken in the agricultural field was the creation of the Food (Defence) Department, which reported in 1938. Up to June 1939, only 150,000 acres of grassland had been broken up for arable production, and tractors were in short supply for war-time purposes. The Government had indeed subsidized the use of lime and basic slag in the interests of soil fertility, but these were home productions, and so the opportunity to increase the reserves in the soil of those nutrients which are mainly imported was missed; and scarcely a beginning had been made with the drainage of water-logged land. The allotment movement, which reached its zenith during 1918-19, was allowed to languish, and no stimulus was given to increased production of vegetables, especially of onions and carrots, which were mostly imported. No plans were made to develop the results of research, conducted by private interests, on ensilage, the use of straw as fodder, or that of urea or ammonium bicarbonate for rectifying protein deficiency in the rations of milch cattle.

This list of omissions is not complete, and the recital of it is distressing, but it will serve to indicate the lamentable shortcomings of past agricultural administrations. The faculty of foresight or prevision is not one that is easily developed; it is, however, a distinguishing feature in the mental equipment of the gifted scientific research worker, and it may therefore be suggested that the inclusion within the administrative body of one or two outstanding men of this type might prevent the recurrence of past ineptitudes. It may be that there is little transfer of insight and predictive ability from scientific research to politics and sociology; experiment alone can decide, and it is worth trying. The fact that the few scientific men who have been elected to Parliament in the past have failed to leave their mark on policy is no evidence to the contrary, because it is not knowledge of science that is the essential qualification-useful though this may be-but sound judgment and ability to look ahead. Improvisation has its place in the casualty ward and on the music-hall stage, but in the sphere of political control it is weak and dangerous. In agriculture at least we must have insight, foresight, and long-term planning.

\section{NUTRITION IN THE HOME}

\section{The Nation's Larder and the Housewife's Part} Therein

A set of Lectures delivered at the Royal Institution of Great Britain in April, May and June 1940, by Prof. J. C. Drummond, Maj.-Gen. Sir Robert McCarrison, Sir John Orr, Sir Frederick Keeble, Dr. L. H. Lampitt, Prof. V. H. Mottram, Dr. J. C. Spence ; with a Supplement by Dr. Franklin Kidd. Pp. xii + 146. (London: G. Bell and Sons, Ltd., 1940.) 2s. 6d. net.

"T THE Nation's Larder" offers to the inquiring housewife much food for thought, perhaps not very easy for her assimilative capacity. A preface by the President of the Royal Society and a letter from the Minister of Food stimulate an appetite for the substantial courses to follow.

It is agreed that in days long past the British peasant's larder was most satisfactorily stocked with a few simple sustaining foods, dairy produce, coarsely ground meal, potatoes, green and root vegetables. In recent years the larder was more variously but less adequately filled, and the nation's health and teeth have suffered from the consumption of sophisticated foodstuffs. War enforces a reversion towards a debased form of peasant's diet, debased because the bread and cereals of which it substantially consists have been deprived of essential ingredients. The majority of the British public are content with white bread, and the few who want wholemeal now have difficulty in getting it. There is an official scheme to reinforce white flour with synthetic vitamin $B_{1}$ (aneurin) and calcium, but that will not restore the protein, the iron and other minerals, and vitamins $A, B_{2}$ and $E$ removed in milling. 